\title{
Determinant of Director Remuneration in Malaysia Public Listed Companies
}

\author{
Syaiful Baharee Jaafar and Kieran James
}

\begin{abstract}
This study examines the relationships between a family firm, the remuneration committee and director remuneration. The proxies of the remuneration committee are the numbers of committee members. The family firm proxy is a family member, as in the board of directors. The dependent variable (director remuneration) is measured by fees, salary, bonuses and benefit of kin. The sample size of this study is 537 firms listed in Bursa, Malaysia with 1611 panel data from 2007 to 2009. This study finds that there is a significant positive relationship between the remuneration committee and director remuneration, which suggests the effectiveness of the monitoring role of the remuneration committee. Furthermore, findings from this study reveal that there is a significant positive relationship between family firms and director remuneration. This study suggests that family members combine power and control to award better remuneration to the board of directors.
\end{abstract}

Index Terms-Director remuneration, remuneration committee, family firm.

\section{INTRODUCTION}

Family firms actively run businesses around the world, which creates diversity in business as well. Faccio and Lang [1] found that, in 13 Western European countries, 44\% of firms were controlled by families or individuals. There is agreat deal of competition, putting pressure on family members to preserve the company in the future. Thus, performance becomes a priority among family members, which requires one to work harder. In order to motivate the board of directors, incentives are required. According to Lazear [2], providing an incentive may possibly affect performance. Through better performance, a family firm has the possibility to expand its business and perhaps increase its wealth.

It is very important to design better remuneration for the family board of directors, including the CEO, to create long-term incentives related to their responsibilities and positions [3]. The remuneration committee has the difficult task of satisfying the board of directors, as well as family members, through remuneration.

The goal of the remuneration committee is to recommend a contract to the board of directors which complies with relevant governance regulations and best practices (MCCG 2012). The committee is responsible for linking the contract with motivation for the board of directors, resulting in better performance. In addition, the committee members mainly consist of non-executives rather than executives so they can

Manuscript received June 15, 2013; revised August 20, 2013.

Syaiful Baharee Jaafar is with Polytechinc Tuanku Sultanah Bahiyan, Malaysia (e-mail: syaiful_1974@yahoo.com.my). monitor the remuneration process. However, non-executives are less independent because they are appointed by executives. This situation creates a conflict of interest between non-executives and executives with respect to remuneration which it is look seem less transparent. According to agency theory, an agency problem occurs when a committee member has a personal interest in increasing wealth via remuneration.

The objective of this paper is to examine the determination of director remuneration by remuneration committees in family firms. The sample size of this study is 537 firms listed in Bursa Malaysia with 1611 panel data from 2007 and 2009. We find that there is a significant positive relationship between the remuneration committee and director remuneration. Further analysis finds evidence that family firms combine power and control to award better remuneration to the board of directors, which provides them with motivation to achieve objectives.

The remaining chapters are organized as follows: Section II outlines the relevant literature, while developing more fully the ideas in past research that are most important to the present study. Research design issues and methodology are explained in Section III. Details of the final sample and the measurement of variables are also discussed in this chapter. The results and discussion are presented in Section IV. Finally, Section V sets out the study's conclusions, limitations, and some suggestions for further research.

\section{LITERATURE REVIEW}

Dissimilar interests between the board of directors and shareholders have implications for a firm's operation. Personal interest is the main objective for the board of directors, which drives them to work harder. On the other hand, the shareholders' intention is to increase wealth via better firm performance. This conflict is known as an agency problem and should be dealt with to ensure the firm's operation is not impeded. Agency theory notes that shareholders hand over authority to the board of directors to run the business on their behalf. Thus, the board of directors has the responsibility to work harder to achieve the firm's objectives and protect shareholders' interests. Remuneration can play a major role as a means to align the interests of the board of directors and the shareholders. Furthermore, a remuneration committee is responsible for proposing better remuneration and approving a contract. The presence of family members in the remuneration committee and board of directors has implications for remuneration.

Remuneration committees have become a subject for many researchers on relations towards remuneration. Previous studies have emphasized the importance of remuneration committees established to plan remuneration 
for boards of directors [4]-[6]. Furthermore, previous studies show the relationship between family firms and remuneration (Cheung et al., 2005; Palmberg, 2009; Cheung et al., 2005).

The literature generally suggests that better remuneration can possibly align the interests of the board of directors and shareholders [7], [8]. When both parties have similar interests, they are able to work together and create better strategies and planning for long-term success. Establishing a remuneration committee makes it possible to propose better remuneration and satisfy the board of directors and the shareholders. Previous studies noted the importance of the presence of a remuneration committee in a firm in order to make better remuneration. Anderson and Bizjak [4] explained that an independent remuneration committee tends to influence remuneration. Conyon [5] and Laing and Wier [6] have argued similarly that the presence of a remuneration committee influences remuneration at the top level.

Remuneration committees tend to use personal and performance criteria as indicators to determine remuneration. Through these indicators, each director is evaluated using a similar process to avoid biases. For example, board members could be evaluated on how they use their personal assets such as skill and knowledge to manage the firm's operation and achieve the firm's objectives. If the board of director has succeeded in achieving objectives, the remuneration committee may propose better remuneration; if not, it may propose less remuneration for less skill and knowledge. Furthermore, the remuneration committee also gets recommendations from human resources for those who work frequently [9].

The remuneration committee should consist of executive and non-executive members to reduce the chances of misleading remuneration. That way the remuneration process is more transparent and tends to come with better remuneration. The reason is that a non-executive director does not have any interest in the firm and works on behalf of minority shareholders. Therefore, the remuneration is awarded in accordance with the remuneration policy and procedure. Lee [10] explains that at the level of the remuneration committee, non-executive directors are required to set pay arrangements by taking into consideration incentives and reward.

Family firms incorporate purposefully for long-term success and prefer to hand over the business to the next generation, such as husband, wife, daughter, son, cousin, grandmother and grandfather. Accordingly, family firms require the board of directors to work harder and maintain better performance. Therefore, the firm should provide better remuneration in order to motivate the board of directors. Lee [11] noticed that families indeed generate influence in business, allowing them to grow faster and be more profitable.

Family firms emphasize achievement of the firm's objectives because it may increase wealth. As a result, this will benefit the future generation. The board of directors play a major role in ensuring that this happens by utilizing its skill, knowledge and talent in connection with the firm's objectives. Regarding to this matter, remuneration should be provided to motivate the board of directors. Furthermore, the board of directors consists of family members, and approving better remuneration will bring benefits for them. First, they will receive a high salary, a large bonus or both [12]. Second, they are major shareholders and will gain better dividends.

A family firm is willing to accept lower remuneration to ensure that the cash flow remains higher. This is important for firm operation either during a financial crisis or when expanding the business. Dogan and Smyth [13] find that the salaries and fees for boards of directors are lower with higher ownership concentration. Furthermore, maintaining the position is very important for family firms to ensure the long term objectives can be achieved. Thus, family members do not bother to receive less remuneration and continue to contribute towards firm. Gomez-Mejia et al. [3] explain that family members are willing to accept lower remuneration to keep a secure position.

\section{RESEARCH MethodOlOGY}

The sample comprises balanced data from 537 firms and 1,611 firm-year observations from Malaysian companies over a 3-year period between 2007 and 2009. The 20072009 period has been chosen because disclosure detailing the activities of the remuneration committee, executive pay structure, level of remuneration and whether the firm is a family firm, as required under the Malaysia Code of Corporate Governance (MCCG), became effective for annual reports after June 2001.

Equation (1) describes the model used to test the relationship between director remuneration, the remuneration committee, the family firm, and control variables:

$$
\begin{aligned}
& \mathrm{REM}=\beta_{0}+\beta_{1} \mathrm{REMCOM}_{i t}+\beta_{2} \mathrm{FAM}_{-} \mathrm{FIRM}_{i t}+ \\
& \beta_{3} \mathrm{SIZE}_{i t}+\beta_{4} \mathrm{DEBT}_{i t}+\beta_{5} \mathrm{AGE}_{i t}+\ldots \\
& \beta_{6} \mathrm{IND}_{i t}+\varepsilon_{i t}
\end{aligned}
$$

Remuneration was measured using proxies representing cash remuneration consisting of salaries, bonuses, benefits of kin, and fees. All remuneration variables are based on logarithm transformations, where the statistical relationship could be weakened and related to skewed distribution and lead heterosdasticity [14]. Remuneration committee measures included the size of remuneration committee, family members as executive director and non-family member as non-executive directors. Size of remuneration committee represents the existence of remuneration committees as suggested by governance.

This study focused on family ownership structure according to two criteria: The first criterion is based on Claessens et al. [15] definition of family as related by blood or marriage and is consistent with others' conceptualizations of family ownership as previously discussed Anderson \& Reeb [16] and Fahlenbrach [17]. Therefore, according to this first criterion, family ownership was measured as members of the board of directors (e.g., CEO, chairman, etc.) who were related by blood or marriage. Annual reports from Bursa Malaysia include disclosure of the relationships among executives under 
board member profiles, which allows for categorization of directors as family members.

Firm size was measured using the natural log of the book value of total assets, which is consistent with how firm size has been measured in prior studies [16], [18]-[20]. Firm age needs to be controlled due to significant impacts of age in this research. Firm age is measure based on time of IPO. Next, industry will be included as a control variable to differentiate between industrial sectors. Industry will be dummy coded with 1 representing the consumer products sector, including trading/service, construction, and plantations/mining, and 0 representing other sectors, including banking, finance, and insurance, which are not included in these analyses [21], [22].

Debt was represented by capital structure, which was computed by dividing long-term debt by total assets [16]. The performance is dependent variable proxy by accounting-based measures such as Return on Assets (ROA) is measured as the ratio of net income to total assets. The interesting fact is that the ROA is the profitability ratios in accounting statements which reflect the shareholders' wealth. Furthermore, ROA is the best measures for current performance [23].

\section{RESULTS AND DISCUSSION}

\section{A. Descriptive}

\begin{tabular}{|c|c|c|c|c|c|}
\hline & Mean & Median & $\begin{array}{c}\text { Standard } \\
\text { Deviation }\end{array}$ & Min & Max \\
\hline \multicolumn{6}{|c|}{ Panel A:Director Remuneration } \\
\hline DIRREM (million) & 2.120 & 1.385 & 4.059 & 0.045 & 70.347 \\
\hline EXECREM (million) & 1.854 & 1.135 & 3.971 & 0.000 & 69.621 \\
\hline EXECFEES (million) & 0.091 & 0.024 & 0.213 & 0.000 & 2.130 \\
\hline EXECSAL (million) & 1.359 & 0.897 & 3.373 & 0.000 & 68.851 \\
\hline EXECBON (million) & 0.219 & 0.000 & 1.170 & 0.000 & 32.111 \\
\hline EXECBEN (million) & 0.184 & 0.039 & 1.072 & 0.000 & 38.165 \\
\hline NEDREM (million) & 0.265 & 0.160 & 0.381 & 0.000 & 5.035 \\
\hline NEDFEES (million) & 0.185 & 0.134 & 0.196 & 0.000 & 2.074 \\
\hline NEDSAL (million) & 0.051 & 0.000 & 0.211 & 0.000 & 3.588 \\
\hline NEDBON (million) & 0.011 & 0.000 & 0.078 & 0.000 & 1.466 \\
\hline NEDBEN (million) & 0.017 & 0.000 & 0.114 & 0.000 & 3.423 \\
\hline \multicolumn{6}{|l|}{ Panel B: Family Firm } \\
\hline FAM_MEM & 1.450 & 0.000 & 1.703 & 0.000 & 6.000 \\
\hline DIR_S̄HARES (\%) & 6.787 & 0.000 & 13.402 & 0.000 & 66.400 \\
\hline INDIR_SHARES (\%) & 14.445 & 0.000 & 20.864 & 0.000 & 84.250 \\
\hline \multicolumn{6}{|l|}{ Panel C: Remuneration } \\
\hline RC_FM & 0.390 & 0.000 & 0.538 & 0.000 & 3.000 \\
\hline RC_NFM & 2.850 & 3.000 & 0.813 & 0.000 & 8.000 \\
\hline REMCOM & 3.230 & 3.000 & 0.674 & 2.000 & 8.000 \\
\hline \multicolumn{6}{|l|}{ Panel D: Control } \\
\hline Variables & 0.030 & 0.037 & 0.122 & -1.139 & 1.426 \\
\hline \multicolumn{6}{|l|}{ ROA } \\
\hline SIZE & 19.542 & 19.417 & 1.317 & 11.755 & 24.496 \\
\hline DEBT & 0.140 & 0.085 & 0.203 & 0.000 & 3.897 \\
\hline AGE & 13.83 & 12.000 & 10.824 & 0.000 & 48.000 \\
\hline
\end{tabular}

Notes: EXECREM and NEDREM are executive and non-executive director remuneration respectively, DIRREM is the total director remuneration respectively. EXECFEES, EXECSAL, EXECBON AND EXECBEN are executive director fees and allowances, salary, bonus and benefit of kin.. NEDFES, NEDSAL, NEDBON AND NEDBEN are nonexecutive director fees and allowances, salary, bonus and benefit of kin respectively. FAM_MEM is family member as in board of director. DIR_SHARES and INDIR_SHARES are direct and indirect shareholding in family firm. RC_FM and RC_NFM are remuneration committee for family members and non family members, respectively. REMCOM is a remuneration committee. ROA is the net income divided by total assets. DEBT is the long term debt over total assets. SIZE is logarithm of total assets and AGE is number of year since incorporate.

Panel A of Table I exhibits the descriptive statistics linked with board of director remuneration. Total board of director remuneration averages RM2.120 million, with a maximum of RM70.347 million. Further, the mean (median) for executive remuneration and non-executive remuneration is RM1.854 (RM1.135) million and RM 265,000 (RM160,000), respectively. In addition, components of executive remuneration, consisting of fees and allowance, salary, bonus and benefit of kin, averages RM91,000, RM1.359 million, RM219,000 and RM184,000, respectively. Furthermore, components of non-executive remuneration are consists of fees and allowance, salary, bonus and benefit of kin averages RM185,000, RM51,000, RM11,000 and RM17,000 respectively. The descriptive findings suggest the obvious, that firms allocate more remuneration for executive remuneration rather than nonexecutive remuneration.

Table II presents the Pearson correlation for the test variables. The Pearson correlation indicates that DIRREM and EXECREM are not correlated with FAM_FIRM. However NEDREM is negatively correlated with FAM_FIRM. This does not provide initial support of the idea that a family firm influences director remuneration. Correlation between NEDREM and RC_NFM is positive and significantly correlated. REMCOM is positively related to the remuneration variables, which provides initial support for the idea that remuneration rewards are based on the procedure and policies of the firm. However, FAM_FIRM is significantly negatively correlated to NEDREM, but not to other remuneration variables.

\section{B. Correlation Matrix}

\begin{tabular}{|c|c|c|c|c|c|c|c|c|c|c|c|c|}
\hline & & EXEC & NED & FAM_ & FAM & & & REM & & & & \\
\hline & DIRREM & REM & REM & MEM & FIRMS & RC_FM & RC_NFM & $\mathrm{COM}$ & ROA & SIZE & DEBT & AGE \\
\hline \multicolumn{13}{|l|}{ DIRREM } \\
\hline EXECREM & $.996^{* 7}$ & & & & & & & & & & & \\
\hline NEDREM & $.277^{* *}$ & $.187^{* *}$ & & & & & & & & & & \\
\hline FAM_MEM & $.060^{*}$ & $.067^{*}$ & $-.063^{*}$ & & & & & & & & & \\
\hline FAM_FIRMS & .020 & .030 & $-103^{* *}$ & $.896^{* \prime}$ & & & & & & & & \\
\hline RC_FM & .014 & .021 & $-.066^{* *}$ & $.717^{*}$ & $.747^{* *}$ & & & & & & & \\
\hline RC_NFM & .043 & .028 & $.167^{* *}$ & $-.453^{* *}$ & $-.488^{* *}$ & $-.568^{* z}$ & & & & & & \\
\hline REMCOM & $.063^{*}$ & $.050^{*}$ & $.149^{* *}$ & .025 & .007 & $.113^{* 8}$ & $.754^{* t}$ & & & & & \\
\hline ROA & $.101^{*}$ & $.095^{* *}$ & $.089^{4 *}$ & $.071^{*}$ & $.062^{*}$ & $.067^{* 3}$ & .040 & $.102^{* *}$ & & & & \\
\hline SIZE & $.357^{* *}$ & $.334^{* *}$ & $.315^{* *}$ & .003 & .033 & .048 & $.102^{* *}$ & $.085^{* *}$ & $.187^{\prime \prime}$ & & & \\
\hline DEBT & $.067^{* *}$ & $.065^{*}$ & .029 & $-065^{* *}$ & $-084^{* z}$ & $-.053^{*}$ & .039 & .005 & -.037 & $.108^{\prime \prime}$ & & \\
\hline AGE & -.005 & -.003 & -.028 & -.016 & .039 & -.030 & .004 & -.019 & .014 & .038 & -.026 & \\
\hline IND & -.008 & .004 & $-.120^{6 *}$ & $.076^{\prime \prime}$ & $.076^{* t}$ & $.110^{* s}$ & $-.151^{* *}$ & $.095^{* *}$ & .021 & $.069^{\prime \prime}$ & .015 & .010 \\
\hline
\end{tabular}

Pearson correlations are reported in the table: EXECREM and NEDREM are executive and non-executive director remuneration; DIRREM is the total director remuneration respectively. FAM_MEM is family member as in board of director. FAM_FIRM is a dummy with $1=$ family firm and $0=$ non family firm. ASSETS total assets. RC_FM and RC_NFM are remuneration committee for family members and non family members, respectively. REMCOM is a remuneration committee. ROA is the net income divided by total assets. Debt is the long term debt over total assets. SIZE is logarithm of total assets and AGE is number of year since incorporate. $*$ and $* *$ denote significance at the $5 \%$ and $1 \%$ level respectively

\section{Multivariate Regression}

The main drawback of univariate analysis is that it examines only one variable at a time. As the independent variables do interact with each other in affecting the dependent variable, multivariate analysis is more appropriate. Table 4.3 indicates results from panel regression determination of remuneration by the 
remuneration committee. This study reveals that director remuneration is influenced by the remuneration committee. Furthermore, column 1 shows that the relationship between the remuneration committee and director remuneration is positive and significant $(0.228 ; t=7.617$ and $p<0.05)$. This finding indicates that the remuneration committee provides effective monitoring of director remuneration.

Furthermore, this study suggests that establishment of a remuneration committee may provide a contract which complies with relevant governance regulations and best practice in connection with individual requirements. This monitoring role may protect shareholder interests from expropriation. In addition, this finding supports the MCCG (2007 revised) recommendation that the remuneration committee should consist mainly or wholly of nonexecutive directors and be responsible for making recommendations on the board of directors in all its forms, drawing from outside advice as necessary. This finding supports Anderson \& Bizjak's [4] argument that the independent remuneration committee has great effect on remuneration.

The panel of regression in columns 1, 2 and 3 indicates that ROA and the size of the firm have a positive and significant impact on director remuneration. This finding suggests that a firm has sufficient provision to award better remuneration due to its strong financial position, which may motive the board of directors to work harder. On the other hand, lower performance has implications for financial matters, resulting in a smaller amount of remuneration being awarded to the board of directors. A firm needs to consider other business operation costs such as creditors, banks, utilities and others. The size of the firm significantly influences director remuneration [24], [25]. This study suggests that executives of small firms are paid less than those in large firms due to financial matters, task complexity and the difficulty of decision-making.

Table III shows the results from panel regression determination of remuneration by family firms. This study shows that director remuneration is influenced by family members. Furthermore, the result of regression in column 1 shows that the relationship between family members and director remuneration is positive and significant $(0.107 ; t=$ 9.150; $p<0.05)$. This finding reveals that family members may combine power and control to award better remuneration to motivate them to work harder. In addition, this study suggests that better remuneration may increase family members' wealth in two ways without abandoning remuneration policies. First, they earn better salary, bonuses and fees and receive better dividends via better performance. In addition, family members should have the privilege to be awarded better remuneration since they are the incorporators, large shareholders and owners of the firm.

It is interesting to note based on the results shown in column 3 that the relationship between family members and non-executive remuneration is negative and significant ($0.076 ; t=-6.134$ and $p<0.05)$. This study suggests that family members may use their privilege as the owners of the firm to reduce non-executive remuneration and responsibilities for business activities because the family members take full responsibility for the business's success and failure.
TABLE III: DETERMINATION OF REMUNERATION BY REMUNERATION COMMITTEE

\begin{tabular}{lccc}
\hline \hline & LN(DIRREM) & LN(EXECREM) & LN(NEDREM) \\
& 1 & 2 & 3 \\
\hline \hline REMCOM & 0.228 & 0.238 & 0.212 \\
& $7.617^{* *}$ & $6.552^{* *}$ & $6.725^{* *}$ \\
ROA & 0.848 & 0.873 & 0.591 \\
& $5.097 * *$ & $4.329^{* *}$ & $3.379 * *$ \\
SIZE & 0.293 & 0.278 & 0.336 \\
& $18.769^{* *}$ & $14.725^{* *}$ & $20.504^{* *}$ \\
DEBT & -0.127 & -0.138 & -0.013 \\
& -1.282 & -1.150 & -0.129 \\
AGE & -0.001 & -0.000 & -0.002 \\
& -0.286 & -0.019 & -1.228 \\
IND & 0.038 & 0.087 & -0.151 \\
& 0.470 & 0.889 & -1.790 \\
CONSTANT & 7.608 & 7.580 & 4.898 \\
& $23.160^{* *}$ & $19.034 * *$ & $14.172^{* *}$ \\
Adjusted $R^{2}$ & & & \\
$F$-statistic & 0.244 & 0.171 & 0.260 \\
& $87.837^{* *}$ & $56.348^{* *}$ & $95.202^{* *}$ \\
Cross-sections & 537 & & \\
Total observation & 1611 & 537 & 537 \\
\hline \hline
\end{tabular}

Notes: EXECREM and NEDREM are executive and non-executive director remuneration; DIRREM is the total director remuneration respectively. REMCOM is size for director and non-executive director in remuneration committee. ROA is the net income divided by total assets. IND "1" is for the consumer products sector; trading/service sector; construction; plantations/mining; and " 0 " if others. DEBT is the long term debt over total assets. SIZE is logarithm of total assets and AGE is number of year since IPO. Significant p-values are bold

\section{Robustness Test}

This sub-section examines the previous result for Hypothesis 2 by an alternative measure of family firms. This study re-estimates the regression (reported in Table 4.3) by replacing family members on the board of directors with direct shareholding by a family member. The result is qualitatively similar to the original result shown in Table 4.4. This result finds evidence that direct shareholding by family members influences director remuneration as shown in regression 1 and 2 of Table IV. The results of the regressions indicate that the coefficient of direct shareholding is positive and significant $(0.006 ; t=3.944$ and $p<0.05$ ) on director remuneration. This study suggests that family members use power via shareholding to propose director remuneration which is recommended by corporate governance regulations.

TABLE IV: DETERMINATION OF REMUNERATION BY FAMILY MEMBER

\begin{tabular}{lccc}
\hline \hline & LN(DIRREM) & LN(EXECREM) & LN(NEDREM) \\
\hline \hline FAM_MEM & 0.107 & 0.140 & -0.076 \\
& $9.150^{* *}$ & $9.988^{* *}$ & $-6.134^{* *}$ \\
ROA & 0.864 & 0.864 & 0.770 \\
& $5.246^{* *}$ & $4.363^{* *}$ & $4.440^{* *}$ \\
SIZE & 0.300 & 0.285 & 0.343 \\
& $19.393^{* *}$ & $15.385^{* *}$ & $20.919^{* *}$ \\
DEBT & -0.067 & -0.060 & -0.052 \\
& -0.015 & -0.511 & -0.500 \\
AGE & -0.001 & -0.000 & -0.003 \\
& -0.310 & -0.003 & -1.494 \\
IND & -0.074 & -0.045 & -0.165 \\
& -0.931 & -0.468 & -1.953 \\
CONSTANT & 8.153 & 8.119 & 5.578 \\
& $25.882 * *$ & $21.461^{* *}$ & $16.666^{* *}$ \\
Adjusted $R^{2}$ & & & \\
$F$-statistic & 0.256 & 0.199 & 0.256 \\
& $93.332^{* *}$ & $67.518^{* *}$ & $93.534^{* *}$ \\
Cross-sections & 537 & & \\
Total observation & 1611 & 537 & 537 \\
\hline \hline
\end{tabular}

Notes: EXECREM and NEDREM are executive and non-executive director remuneration; DIRREM is the total director remuneration respectively. FAM_MEM is family member as in board of director. ROA is the net income divided by total assets. IND "1" is for the consumer products sector; trading/service sector; construction; plantations/mining; and "0" if others. DEBT is the long term debt over total assets. SIZE is logarithm of total assets and AGE is number of year since IPO. Significant p-values are bold 


\section{CONCLUSION}

This study examines the relationships between family firms, remuneration committees and director remuneration. The proxy of remuneration committee is the numbers of committee members. The family firm proxy is a family member, as in the board of directors. The dependent variable (director remuneration) is measured by fees, salary, bonuses and benefit of kin. The sample size of this study is 537 firms listed in Bursa Malaysia, with 1611 panel data from 2007 to 2009. This study finds that there is a significant positive relationship between the remuneration committee and director remuneration, which suggests the effectiveness of the monitoring role of the remuneration committee. In addition, findings from this study indicate that there is a significant positive relationship between family firms and director remuneration. This study suggests that family members combine power and control to award better remuneration to the board of directors, which provides them with motivation for long-term success. A limitation of this study is related to the changing of ownership and may be not generalizable to others periods. Further research may use family members on the remuneration committee as a proxy for the remuneration committee. Such investigation could provide useful insight into the role of remuneration committees in family firms in enhancing agency cost.

\section{REFERENCES}

[1] M. Faccio and L. Lang, "The ultimate ownership of Western European corporations* 1," Journal of Financial Economics, vol. 65, no. 3, pp. 365-395, 2002.

[2] E. Lazear, "Performance pay and productivity," American Economic Review, pp. 1346-1361, 2000.

[3] L. Gomez-Mejia, M. Larraza-Kintana, and M. Makri, "The determinants of executive compensation in family-controlled public corporations," The Academy of Management Journal, pp. 226-237, 2003.

[4] R. Anderson and J. Bizjak, "An empirical examination of the role of the CEO and the compensation committee in structuring executive pay* 1," Journal of Banking \& Finance, vol. 27, vol. 7, pp. 13231348, 2003.

[5] M. Conyon, "Corporate governance and executive compensation," International Journal of Industrial Organization, vol. 15, no. 4, pp. 493-509, 1997.

[6] C. Weir and D. Laing, "Governance structures, director independence and corporate performance in the UK," European Business Review, vol. 13, no. 2, pp. 86-95, 2001.

[7] M. Jensen and W. Meckling, "Theory of the firm: Managerial behavior, agency costs and ownership structure," Journal of Financial Economics, vol. 3, no. 4, pp. 305-360, 1976.

[8] E. Fama and M. Jensen, "Separation of ownership and control," The Journal of law and Economics, vol. 26, no. 2, pp. 301, 1983.

[9] M. Jensen, K. Murphy, and E. Wruck, CEO Pay and How to Fix It, Working Paper, Harvard Business School, 2005.

[10] J. Lee, "Executive performance-based remuneration, performance change and board structures," The International Journal of Accounting, vol. 44, no. 2, pp. 138-162, 2009.
[11] J. Lee, "Family firm performance: Further evidence," Family Business Review, vol. 19, no. 2, pp. 103-114, 2006.

[12] S. Basu et al., "Corporate governance, top executive compensation and firm performance in Japan," Pacific-Basin Finance Journal, vol. 15 , no. 1 , pp. 56-79, 2007.

[13] E. Dogan and R. Smyth, Board Remuneration, Company Performance, and Ownership Concentration: Evidence from Publicly Listed Malaysian Companies, ASEAN Economic Bulletin, vol. 19, no. 3, pp. 319-347, 2002.

[14] B. G. Tabachnick and L. S. Fidell, Using Multivariate Statistics 2007, Pearson/Allyn \& Bacon.

[15] S. Claessens et al., "Disentangling the incentive and entrenchment effects of large shareholdings," The Journal of Finance, vol. 57, no. 6, pp. 2741-2771, 2002.

[16] R. Anderson and D. Reeb, "Founding-family ownership and firm performance: Evidence from the S\&P 500," Journal of Finance, vol. 58, no. 3, pp. 1301-1328, 2003.

[17] R. Fahlenbrach, "Founder-CEOs, investment decisions, and stock market performance," The Journal of Financial and Quantitative Analysis, 2007.

[18] K. Chalmers, P. Koh, and G. Stapledon, "The determinants of CEO compensation: Rent extraction or labour demand?" The British Accounting Review, vol. 38, no. 3, pp. 259-275, 2006.

[19] B. Maury, "Family ownership and firm performance: Empirical evidence from Western European corporations," Journal of Corporate Finance, vol. 12, no. 2, pp. 321-341, 2006.

[20] M. J. Conyon and S. I. Peck, "Board control, remuneration committees, and top management compensation," Academy of Management Journal, vol. 41, no. 2, pp. 146-157, 1998.

[21] A. Carrasco-Hernandez and G. Sanchez-Marin, "The determinants of employee compensation in family firms: empirical evidence," Family Business Review, vol. 20, no. 3, pp. 215, 2007.

[22] J. Martinez, B. Stohr, and B. Quiroga, "Family ownership and firm performance: Evidence from public companies in Chile," Family Business Review, vol. 20, no. 2, pp. 83, 2007.

[23] M. Cornett et al., "The impact of institutional ownership on corporate operating performance," Journal of Banking \& Finance, vol. 31, no. 6, pp. 1771-1794, 2007.

[24] M. Jensen and K. Murphy, "Performance pay and top-management incentives," Journal of Political Economy, vol. 98, no. 2, pp. 225-264, 1990.

[25] R. Bliss and R. Rosen, "CEO compensation and bank mergers* 1," Journal of Financial Economics, vol. 61, no. 1, pp. 107-138, 2001.

Syaiful Baharee Jaafar was born in Malaysia in 1974. He received his BAC (Hons.) majoring in Accounting from National University of Malaysia (UKM) in 1998 and M. Ed. from the University of Technology Malaysia (UTM) in 2000. In 2013 he received his Ph.D. in Accounting from University of Southern Queensland (USQ), Australia. He is currently a Dr. with the Commerce Department, Polytechnic Tuanku Sultanah Bahiyah, Malaysia. His research interest in corporate governance includes director remuneration and remuneration committee in family firm. He has published papers in few journals.

Kieran James is a professor in Accounting at University of Fiji, Sawen campus, Fiji Islands. He has 22 years' teaching experience in Australia, Fiji, and Singapore. He has published over 40 scholarly articles in leading journals including Accounting Auditing and Accountability Journal, Critical Perspectives on Accounting, International Journal of Critical Accounting, Korean Journal of Industrial Relations, and Musicology Australia. His main research interests are: accounting education; business ethics education; critical and Marxist perspectives on accounting and the labour process; employment prospects in accounting for minority groups; trade union strategy and immigrant worker issues; Singapore opposition politics and oppositional youth activism; and the sociology of death-metal and punk music scenes. 